6. Bogardus C, Ravussin E, Robbins DC, Wolfe RR, Horton ES, Sims EAH (1983) Effects of physical training and diet therapy on carbohydrate metabolism in patients with glucose intolerance and non-insulin-dependent diabetes mellitus. Diabetes (in press)

7. Vranic M, Horvath W, Wahren J (eds) (1979) Proceedings of a Conference on Diabetes and Exercise. Diabetes 28: Suppl 1

8. Berger M, Christacopoulos P, Wahren J (eds) (1982) Diabetes and exercise. Current problems in clinical biochemistry 11. Hans $\mathrm{Hu}-$ ber, Bern Stuttgart Vienna

9. Kemmer FW, Berger M (1983) Exercise and diabetes mellitus: physical activity as a part of daily life and its role in the treatment of diabetic patients. Int J Sports Med 4: 77-88

10. Jackson JE, Bressler R (1982) Oral hypoglycemics and drug interaction with them and insulin. In: Brodoff BN, Bleicher SJ (eds) Diabetes mellitus and obesity. Williams \& Wilkins, Baltimore, pp $462-479$

Dr. E. A.H.Sims

Metabolic Unit

Department of Medicine

College of Medicine

University of Vermont

Burlington, VT 05405

USA

\section{Insulin internalization in human erythrocytes}

\section{Dear Sir}

In a recent Letter to the Editor, Bihr et al. [1] concluded from their studies that "(1) insulin binding is not necessarily followed by internalization of insulin; (2) only cells with nuclei internalize insulin; (3) insulin may well exert different effects on intracellular metabolism depending upon nuclei content; and (4) reticulocytes that can internalize insulin might be of importance concerning the rate of insulin degradation in circulating blood."

In contrast with these suggestions, we take the following view. Bihr et al. used electron microscopy to show insulin internalization in blood cells [1]. Prior to this technique, biochemical methods involving receptor down-regulation in vitro pioneered studies of insulin internalization [2]. Unlike electron microscopy, the biochemical methods can evaluate various physiological actions involved in insulin receptor down-regulation and insulin internalization [3]. These biochemical studies are equally important and should be considered simultaneously before arriving at any conclusion from electron microscopic studies of insulin internalization.

The first conclusion by Bihr et al was apparently based upon electron microscopic observations of insulin bound to human erythrocytes. They did not specify the temperature and incubation time for insulin binding prior to the observation.

However, binding is similar at $0^{\circ} \mathrm{C}$ and $4^{\circ} \mathrm{C}$ for both nucleated cells [4] and human erythrocytes. We have shown that $91 \%-98 \%$ of bound insulin at $4{ }^{\circ} \mathrm{C}$ is extractable and the extractable insulin is intact [5]. At $15^{\circ} \mathrm{C}$, after $3.5 \mathrm{~h}$ of binding, $80 \%$ of bound insulin is extractable and $60 \%$ of the extractable insulin is intact, while at $37^{\circ} \mathrm{C}$, with increasing time of incubation, the extractability of cell-bound insulin and the proportion of intact, undegraded, extractable insulin decreases. Since the degradation of insulin in these erythrocytes can only be by cytosolic enzyme [7], degradation is a measure of internalization. Thus, these findings clearly show that insulin internalization is time- and temperature-dependent in human erythrocytes.

In contrast with the second conclusion of Bihr et al. [1], our published data [5-8] provided the following evidence of insulin internalization by human erythrocytes at $37^{\circ} \mathrm{C}$ : (a) human erythrocyte cell membranes lack an insulin degrading enzyme [6]; (b) there is a very specific and potent insulin degrading enzyme in cell cytosol (7.8); (c) there is a time-dependent continuous increase in insulin association with the cells at $37^{\circ} \mathrm{C}$ [6]; and (d) about $56 \%$ of the cell-associated insulin is degraded at the end of $5 \mathrm{~h}$ of incubation at $37^{\circ} \mathrm{C}$ [6]. Moreover, according to biochemical studies performed to evaluate insulin receptor down-regulation (and thereby assess insulin internalization) in IM-9 lymphocytes (nucleated cells), contradictory results were obtained by Baldwin et al. [9], that is, insulin internalization was not observed.

Reticulocytes are known not to have nuclei. They are capable of limited protein synthesis due to performed mRNA, although they cannot synthesize mRNA [10]. Thus, Bihr et al. should not have seen insulin internalization in reticulocytes. Therefore, their fourth conclusion is contradictory to their second.

Bihr et al. [1] have drawn their conclusions without referring to the contradictory state of current published reports. We have demonstrated insulin internalization in mature human erythrocytes, which do not possess nuclei.

Yours sincerely,

S. G. Nerurkar and K. K. Gambhir

\section{References}

1. Bihr X, Thun C, Pfeiffer EF (1983) Nucleated blood cells bind and internalize insulin. Diabetologia 24: 69-70 (Letter)

2. Gavin JR III, Roth J, Neville DM, Jr, De Meyts P, Buell DN (1974) Insulin-dependent regulation of insulin receptor concentrations: a direct demonstration in cell culture. Proc Natl Acad Sci (USA) 71:84-88

3. Bishayee S, Das M (1982) Insulin degradation in 3T3-L1 adipocytes: role of endocytic lysosomal pathway. Arch Biochem Biophys 214: $425-429$

4. Pastan IH, Willingham MC (1981) Journey to the center of the cell: role of receptorsome. Science 214: 504-509

5. Gambhir KK, Nerurkar SG, Archer JA (1982) Post-receptor transport and degradation of insulin in human erythrocytes. Clin Res 30: $392 \mathrm{~A}$

6. Gambhir KK, Nerurkar SG, Das PD, Archer JA, Henry WL Jr (1981) Insulin binding and degradation by human erythrocytes at physiological temperature. Endocrinology 109: 1787-1789

7. Nerurkar SG, Gambhir KK (1981) Insulin degradation by human erythrocyte lysates. Clin Chem 27:607-608

8. Gambhir KK, Nerurkar SG (1982) Intracellular specific insulin degrading enzyme in human erythrocytes. Proceedings of the 64th Annual Meeting of the Endocrine Society. Endocrinology 110 (Suppl): 168 (Abstract) 355

9. Baldwin D Jr, Prince M, Marshall S, Davies P, Olefsky JM (1980) Regulation of insulin receptors: evidence for involvement of an endocytotic internalization pathway. Proc Natl Acad Sci (USA) $77: 5975-5978$

10. Ginsberg BH, Brown TJ (1982) Regulation of insulin receptors in erythroid cells. Metabolism 32: 728-732

Dr. K. K. Gambhir

Molecular Endocrinology Laboratory

Department of Medicine

Howard University

2041 Georgia Avenue, NW

Washington, DC-20060

USA

\section{Adenine nucleotide metabolism in diabetes}

Dear Sir,

In a recent paper in this journal, Bakhle and Chelliah [1] demonstrated a modest decrease in the uptake and metabolism of adenosine diphosphate $(A D P)$ in perfused lungs removed from rats rendered 
Table 1. Red cell adenine nucleotides and their metabolism in diabetic patients and control subjects

\begin{tabular}{|c|c|c|c|c|c|}
\hline \multirow[t]{2}{*}{$\begin{array}{l}\text { Red cell nucleo- } \\
\text { tide content } \\
\left(\mathrm{nmol} / 10^{8} \text { cells }\right)\end{array}$} & & \multicolumn{4}{|c|}{$\begin{array}{l}\% \text { ADP or metabolite present after } \\
\text { incubation of }{ }^{14} \mathrm{C}-\mathrm{ADP} \text { with test plasma } \\
\text { at } 37^{\circ} \mathrm{C}\end{array}$} \\
\hline & & $0 \mathrm{~min}$ & $5 \min$ & $15 \mathrm{~min}$ & $30 \mathrm{~min}$ \\
\hline \multicolumn{6}{|c|}{ Control subjects $(n=19)$} \\
\hline $\begin{array}{ll}\text { ATP } & 10.53 \\
& (8.0-16.2)\end{array}$ & ÁDP & $\begin{array}{l}89 \\
(88-93)\end{array}$ & $\begin{array}{l}73 \\
(59-83)\end{array}$ & $\begin{array}{l}49 \\
(35-68)\end{array}$ & $\begin{array}{l}32 \\
(16-39)\end{array}$ \\
\hline $\begin{array}{ll}\text { ADP } & 1.20 \\
& (0.1-2.5)\end{array}$ & AMP & $\begin{array}{l}5 \\
(4-6)\end{array}$ & $\begin{array}{l}20 \\
(14-30)\end{array}$ & $\begin{array}{l}34 \\
(26-46)\end{array}$ & $\begin{array}{l}35 \\
(20-48)\end{array}$ \\
\hline & nosine & $\begin{array}{c}1 \\
(0.7-1.5)\end{array}$ & $\begin{array}{l}2 \\
(1-2.5)\end{array}$ & $\begin{array}{l}6 \\
(2-11)\end{array}$ & $\begin{array}{l}23 \\
(4-39)\end{array}$ \\
\hline & & & $(n=12)$ & & \\
\hline \multicolumn{6}{|c|}{ Diabetic patients $(n=31)$} \\
\hline $\begin{array}{l}\text { ATP } 10.93 \\
(8.6-13.4)\end{array}$ & ADP & $\begin{array}{l}92 \\
(91-93)\end{array}$ & $\begin{array}{l}72 \\
(59-89)\end{array}$ & $\begin{array}{l}46 \\
(32-66)\end{array}$ & $\begin{array}{l}31 \\
(17-45)\end{array}$ \\
\hline \multirow[t]{3}{*}{ ADP 1.72} & AMP & $\begin{array}{l}4 \\
(2-6)\end{array}$ & $\begin{array}{l}18 \\
(7-25)\end{array}$ & $\begin{array}{l}32 \\
(22-46)\end{array}$ & $\begin{array}{l}35 \\
(18-45)\end{array}$ \\
\hline & nosine & $\begin{array}{l}1 \\
(0.7-2)\end{array}$ & $\begin{array}{l}1.5 \\
(0.7-5)\end{array}$ & $\begin{array}{l}7 \\
(1-15)\end{array}$ & $\begin{array}{l}19 \\
(5-37)\end{array}$ \\
\hline & & & $(\mathrm{n}=24)$ & & \\
\hline
\end{tabular}

Results are expressed as medians with ranges in parentheses. The statistical analysis used was the Wilcoxon rank sum test

diabetic by streptozotocin administration. The authors go on to suggest that this may contribute to the platelet hyperaggregability often observed in diabetes.

In order to investigate this hypothesis further, particularly its significance in the systemic circulation, we have measured ADP-degrading activity in plasma derived from peripheral blood taken from normal subjects and from insulin-dependent and non-insulin-dependent diabetic patients under various degrees of diabetic control (as gauged by glycosylated haemoglobin concentration). The methods used were as previously described [2] and our results are shown in Table 1.

No measurable ATP or ADP was detected in platelet-depleted plasma in any group nor was the ability of such plasma to metabolise ADP different in diabetics compared to controls. The major metabolite was adenosine monophosphate, although significant amounts of adenosine were produced after prolonged (15-30 min) incubation. Again, no significant differences between controls and diabetics were noted.

Because of the proposal [3] that platelet hyper-reactivity in diabetes might be secondary to decreased red cell deformability resulting in increased red cell disruption and ADP release in the microcirculation, we also measured red cell adenine nucleotide content and release in the different groups of diabetic patients. No significant differences between controls or the various patient groups were noted in either nucleotide content (Table 1) or in the release of ATP or ADP from washed red cell suspensions subjected to moderate agitation (stirring at $1000 \mathrm{rev} / \mathrm{min}$ in a platelet aggregometer). We have not excluded the possibility that decreased deformability of diabetic red cells might result in greater disruption of these cells in the microcirculation or that this might contribute significantly to the prothrombotic events in vivo in such patients, although it seems unlikely that these changes could contribute to the hyperactivity of diabetic platelets in vitro.

In summary, we found nothing to substantiate the contention that metabolism of ADP is decreased in diabetes. The possible modest decrease of such activity observed by the analysis of the effluent of perfused lungs in rats [1] was not apparent in plasma derived from blood collected from peripheral veins in our studies in man and it is therefore unlikely to be of major significance to the generalized vascular pathology of diabetes. Two further possibilities, however, have to be considered. Firstly, the differences in ADP-ase activity may be more marked at the cell surface, and secondly, such differences may be better reflected in arterial blood especially if pulmonary vasculature makes a contribution to it. These aspects are under investigation in our laboratory.

Also under investigation is the fact that platelet hyperaggregability in diabetes appears to be related to the concomitant presence of macrovascular disease [4], and that an alteration in ADP-ase activity at the endothelial cell surface may contribute to it.

Yours sincerely,

R.A. Hutton, M.A. Barradas, R. de Albarran and P.Dandona

\section{References}

1. Bakhle YS, Chelliah R (1983) Effect of streptozotocin-induced diabetes in the metabolism of ADP, AMP and adenosine in the pulmonary circulation of rat isolated lung. Diabetologia 24: 455-459

2. Barradas M, Khokher A, Hutton RA, Craft IL, Dandona P (1983) Adenosine diphosphate degrading activity in placenta. Clin Sci 64 : 239-241

3. Juhan I, Buonocore M, Jouve R, Vague P, Moulin JP, Vialottes B (1982) Abnormalities of erythrocyte deformability and platelet aggregation in insulin dependent diabetics corrected by insulin in vivo and in vitro. Lancet $1: 535-537$

4. Mikhailidis DP, Jeremy JY, Barradas MA, Mohiuddin J, Gracey L, Dandona P (1983) Endogenous platelet thromboxane $A_{2}$ production in diabetic patients with and without peripheral vascular disease. Diabetologia 25: 180-181 (Abstract)

Dr. R. A. Hutton

Katharine Dormandy Haemophilia Centre and Haemostasis Unit

Royal Free Hospital

Pond Street

London NW3 2QG

UK 